\title{
Quality attributes of pistachio nuts as affected by rootstock and deficit irrigation
}

\author{
Ángel A Carbonell-Barrachina, Houssem Memmi, Luis Noguera-Artiaga, \\ María del Carmen Gijón-López, Rafał Ciapa and David Pérez-López
}

\section{INTRODUCTION}

Pistachio is a drought-tolerant fruit tree species which is an interesting alternative to other traditional Mediterranean crops with higher need of water, such as vineyards. Iran, USA and Turkey are the major world producers of pistachio, while Spain has increased pistachio-cultivated fields from almost negligible in 1990 to about 5000 ha in 2013. Pistachio is mainly grown under rain-fed conditions in the Mediterranean basin, but irrigation significantly increases yield. In general, irrigation also improves pistachio quality (higher percetange of split shells) and dampens the alternate bearing pattern. ${ }^{1-3}$ The good performance of pistachio trees under dryland conditions and the favourable response to irrigation are both very important issues, considering that water is a scarce resource and, in the very near future, only the most efficient agricultural systems are likely to receive irrigation water. ${ }^{3,4}$

Regulated deficit irrigation (RDI) is a system of managing water supply by imposing some water deficits in specific phenological stages, which have been found to be less sensitive, with no or low reduction in economic benefits. ${ }^{5,6}$ Pistachio nut development consists of three different periods: (i) stage/ starts at the beginning of nut growth, ending when maximum nut size is reached; (ii) stage II is the period in which the shell hardens; and finally (iii) stage III is the period of growth of the edible part. ${ }^{2}$

In general, it is quite well established that water deficit influences a wide variety of physiological processes in higher plants, including leaf expansion, stomatal opening and photosynthetic carbon assimilation. ${ }^{7}$ The existence of different mechanisms of drought resistance, operating at different pistachio phenological stages, has been recently demonstrated by Gijón et al. ${ }^{5}$ However, the effects of water deficit on the quality of pistachios have not been studied in detail.

Fruits and vegetables, including pistachios, cultivated under RDI and called 'hydrosustainable' products, will have a solid identity (higher content of bioactive compounds, higher intensity of some sensory attributes, etc.); they will be environmentally friendly and will also optimize the use of a very valuable resource in the world: water.

Pistachio cultivation requires the use of rootstocks, and grafting is the only form of vegetative propagation. The main pistachio rootstocks are Pistacia integerrima L., P.atlantica Desf., P. terebinthus $L$. and $P$. vera $L$. The most used rootstock in Iran is $P$. vera $L$.; in the USA $P$. integerrima $L$. and a hybrid between $P$. integerrima and $P$. atlantica Desf. (UCB) are most used; and in the Mediterranean basin it is $P$. terebinthus $L$. There are only few studies ${ }^{3,8,9}$ comparing 
drought and cold resistance, susceptibility to frost and/or tolerance to verticillium in different pistachio rootstocks; however, studies focused on the evaluation of the effect of rootstocks on the quality of edible nuts were not found in the literature.

For all of the above reasons, the main aim of the current study was to evaluate the effects of two factors: (i) irrigation treatment under RDI conditions and (ii) rootstock on the quality of pistachio nuts. Three rootstocks were used: $P$. atlantica, $P$. integerrima and $P$. terebinthus. Three irrigation treatments were assayed: T0, in which trees were irrigated to avoid hydric stress; and T1 and T2, in which hydric stresses were applied at different levels during stage II (shell hardening). The quality of the edible pistachio nuts was studied from different points of view (i) morphology: yield per tree, nut weight and size; (ii) physicochemical: $\mathrm{CIE} L^{*} a^{*} b^{*}$ colour, fatty acid profile, mineral content and profile of volatile compounds; and (iii) sensory: descriptive profile using a trained panel, and consumer acceptance in four countries (Spain, Poland, France and Slovak Republic).

\section{MATERIALS AND METHODS}

Plant material, growing conditions and experimental design

Pistachio trees, cultivar Kerman, were grown during 2012 and 2013, on the experimental farm 'El Chaparrillo' located in Ciudad Real (Spain), ( $3^{\circ} 56^{\prime} \mathrm{W}, 39^{\circ} \mathrm{N}$; altitude $640 \mathrm{~m}$ above sea level). The climate of the study area is Mediterranean, with an average annual rainfall of $397 \mathrm{~mm}$. The soil is a shallow clay-loam (Petrocalcic Palexeralfs) of $0.5 \mathrm{~m}$ depth and with a discontinuous petrocalcic horizon around $0.5 \mathrm{~m}$.

The study was conceived using a factorial design with two replicates and two factors: (i) irrigation treatment and (ii) type of rootstock. Each combination of irrigation treatment and rootstock involved a total of four pistachio trees (two experimental plots, replications, with two trees in each plot). Three irrigation treatments were evaluated: (i) TO or control, in which trees were irrigated with enough volume of water to completely avoid hydric stress; (ii) T1: during phase II irrigation was suppressed until pistachio trees reached a stem water potential (SWP) below $-1.3 \mathrm{MPa}$, then irrigation was managed to keep SWP below this threshold but near of it; and (iii) T2 had the same irrigation protocol as T1 but with a SWP threshold of $-1.5 \mathrm{MPa}$. Pistachio trees subjected to deficit irrigation treatments $\mathrm{T} 1$ and $\mathrm{T} 2$ were rehydrated when phase III started. Pistachio trees ( $P$. vera) were grafted over three different rootstocks: $P$. atlantica, $P$. integerrima and $P$. terebinthus.

Water relations were characterized during the season, moreover with three diurnal cycles of midday stem water potential $\left(\Psi_{x}\right)$ and abaxial leaf conductance. $\Psi_{x}$ was measured using a pressure chamber (Soilmoisture Equipment Corp., Santa Barbara, CA, USA). One leaf was taken from each tree in each experimental plot for measurements. The leaf subject to measurement was selected from the middle and shaded side of the canopy to avoid a sharp change in its state. It was then covered with aluminium foil $1 \mathrm{~h}$ before measurement, stopping transpiration, and enabling the leaf to come into equilibrium with the water potential of the stem. Owing to the difficulty in the determination of SWP in pistachio trees due to turpentine exudation, a piece of blotting paper was placed above the petiole cut-off to facilitate measurement, since paper does not wet with turpentine but does so with xylem water. ${ }^{4,5}$

Pistachio nuts were harvested on 27 September 2012 and 26 September 2013. Pistachio nuts from the two trees in each experimental plot (combination of irrigation treatment and rootstock) were collected and thoroughly mixed to obtain a homogeneous sample. Same-day pistachios were collected from the field, peeled and dried in a convection oven with hot air at $60^{\circ} \mathrm{C}$ until the targeted moisture content of $7 \%$ ( $\sim 3$ days) was reached. Nuts were immediately packed and approximately $2 \mathrm{~kg}$ were posted from Ciudad Real (Spain) to Orihuela (Alicante, Spain) for analyses. Results shown in this study are the mean value of two consecutive seasons: 2012 and 2013; however, the consumer study was conducted using pistachios only from the 2013 season.

\section{Sample processing (salting and toasting)}

Pistachios ( $100 \mathrm{~g}$ portions) were soaked in $20 \% \mathrm{NaCl}$ in water (w/v) for $30 \mathrm{~min}$ with continuous stirring. Salted nuts were left to dry at room temperature for $30 \mathrm{~min}$ to release the excess of water. Pistachios were then toasted in a microwave oven (LG Wavedom, LG electronics, Seoul, South Korea) at $480 \mathrm{~W}$ for $8 \mathrm{~min}$; each sample was thoroughly mixed for $2 \mathrm{~min}$ to avoid local overheating. Under these microwave conditions, toasting of pistachios was equivalent to that reached under commercial conditions $\left(135^{\circ} \mathrm{C}\right.$ for $20 \mathrm{~min})$. Samples were left to cool to room temperature ( $\sim \mathrm{h}$ ). Finally, samples were vacuum packed and kept under refrigeration $\left(4-5^{\circ} \mathrm{C}\right)$ until analysis. The roasting processing was conducted in triplicate.

\section{Physicochemical analyses \\ Fruit yield}

The yield of each irrigation treatment and rootstock was evaluated in terms of total weight (kilograms per tree).

\section{Weight and size}

Twenty-five pistachio nuts from each treatment were randomly selected and the whole nut, shell and edible part were weighed (model AG204 scale; Mettler Toledo, Barcelona, Spain) with a precision of $0.1 \mathrm{mg}$. Later, the three dimensions (length, width and height) of the edible part of each one of the 25 pistachios taken per treatment were measured using a digital caliper (model 500-197-20 150 mm; Mitutoyo Corp., Aurora, IL, USA).

\section{Colour determination}

Colour determinations were made at $25 \pm 1{ }^{\circ} \mathrm{C}$ using a colorimeter (model CR-300, Minolta, Osaka, Japan). This spectrophotometer uses an illuminant $D_{65}$ and a $10^{\circ}$ observer as references. In order to reduce data variability, ground pistachios (grinding for $10 \mathrm{~s}$ in a grinder (Taurus Aromatic Ver Il; Taurus Group, Barcelona, Spain) were placed on Petri dishes $(100 \times 15 \mathrm{~mm})$; the colour of individual pistachios is very heterogeneous and measurement of a mixture of several nuts will decrease data variability by increasing the homogeneity of the material under evaluation. Colour data were provided as CIE $L^{*} a^{*} b^{*}$ coordinates, which define the colour in a three-dimensional space. $L^{*}$ indicates lightness, taking values within the range $0-100$, and $a^{*}$ and $b^{*}$ are chromatic coordinates: green-red and blue-yellow, respectively. The coordinate $a^{*}$ takes positive values for reddish colours and negative values for greenish ones, whereas $b^{*}$ takes positive values for yellowish colours and negative values for bluish ones. Finally, $C^{*}$ is chroma $\left(C *_{a b}=\sqrt{\left(a *^{2}\right)+\left(b *^{2}\right)}\right) ; 0$ is at the centre of a colour sphere and increases according to the distance from the centre. Colour analyses were run in ten replicates for each pistachio cultivar. 
Water activity

Water activity of pistachio samples was measured using an $a_{w}$ meter (Novasina aw-Sprint TH500; Pfaffikon, Zurich, Switzerland). To carry out the measurement, 20 pistachios from each of the treatments and rootstocks were finely ground, as previously described for colour measurement. The analysis was performed in triplicate.

\section{Cutting force}

Pistachio nuts hardness was evaluated using a texture analyser (model TA-XT2i; Stable Micro Systems, Godalming, UK) equipped with a $25 \mathrm{~kg}$ load cell capacity. Pistachio nuts were horizontally placed on the plate and cutting test was carried out using a knife blade (HDP/BS). The cutting test is an empirical indicator of the force needed to cut a particular food. Cutting was performed at $1 \mathrm{~mm} \mathrm{~s}^{-1}$ until the pistachio was fully cut; results were expressed in newtons. The test was performed in 20 replicates $(n=20)$.

\section{Oil content and analysis of fatty acids}

A $1 \mathrm{~L}$ ultrasonic bath (model 3000512, JP Selecta s.a., Barcelona, Spain) with constant frequency $(40 \mathrm{kHz})$ was used to extract pistachio nut oil by sonication. A ground-nut portion ( $1 \mathrm{~g}$ ) was mixed with $3 \mathrm{~mL} n$-hexane and the mixture was sonicated in an ultrasonic bath at room temperature for $3 \mathrm{~h}$. The mixture was centrifuged and the oil was recovered by evaporating the $n$-hexane using a nitrogen stream. The weight of the oil obtained was used to calculate the oil content (\%) of each pistachio sample.

Fatty acid methyl esters (FAME) were prepared according to the method described by Majdi et al., ${ }^{10}$ with some modifications. Extracted oil $(50 \mathrm{mg}$ ) was saponified with $100 \mu \mathrm{L}$ dichloromethane $\left(\mathrm{Cl}_{2} \mathrm{CH}_{2}\right)$, and $1 \mathrm{~mL}$ methanolic $\mathrm{NaOH}$ solution by refluxing for $10 \mathrm{~min}$ at $90^{\circ} \mathrm{C}$. After addition of $1 \mathrm{~mL}$ methanolic $\mathrm{BF}_{3}(14 \%)$, the sample was boiled for $10 \mathrm{~min}$. The fatty acid methyl esters were extracted from a salt-saturated mixture by adding $600 \mu \mathrm{L}$ hexane. The organic layer was separated and used for analysis by gas chromatography-mass spectrometry (GC-MS). The GC-MS set up (GC-17A and GCMS-QP5050A), described in detail in the section of volatile compounds below, was used for the identification and quantification of fatty acid methyl esters. Injector and detector temperatures were held at 230 and $300^{\circ} \mathrm{C}$, respectively. The GC program was as follows: (i) initial temperature $80^{\circ} \mathrm{C}$ for $2 \mathrm{~min}$; (ii) rate of $8^{\circ} \mathrm{C} \mathrm{min}-1$ from 80 to $160^{\circ} \mathrm{C}$; (iii) rate of $4^{\circ} \mathrm{C} \mathrm{min}^{-1}$ from 160 to $240^{\circ} \mathrm{C}$ and held for $30 \mathrm{~min}$. Identification of peaks was made by comparison with FAME standards from Sigma-Aldrich. Analysis of FAME was run in triplicate $(n=3)$.

\section{Mineral analysis}

Approximately $0.5 \mathrm{~g}$ ground pistachios was digested for $2 \mathrm{~h}$ at a temperature below $130^{\circ} \mathrm{C}$, in a multi-place digestion block (Digest 20, Selecta) using $5 \mathrm{~mL}$ of $65 \%(\mathrm{w} / \mathrm{v}) \mathrm{HNO}_{3}$ according to the method described by Carbonell-Barrachina et al. ${ }^{11}$ Samples were left to cool to room temperature, transferred to a volumetric flask and dilutions of 1:10 and 1:50 were prepared using ultra-high-purity deionized water. Samples were stored at $4{ }^{\circ} \mathrm{C}$ until analysis.

Determination of $\mathrm{Ca}, \mathrm{Mg}, \mathrm{K}, \mathrm{Na}, \mathrm{Cu}, \mathrm{Fe}, \mathrm{Mn}$ and $\mathrm{Zn}$ in previously mineralized samples was performed using an atomic absorption-emission spectrometer (Solaar 969; Unicam Ltd, Cambridge, UK). Potassium and sodium were analysed using atomic emission the other elements by atomic absorption.

Instruments were calibrated using certified standards. In each analytical batch, at least two reagents blanks - one international
Table 1. Yield ( $\mathrm{kg}$ per tree) and nature of pistachios as affected by deficit irrigation treatments and rootstock

\begin{tabular}{|c|c|c|c|c|c|c|}
\hline \multirow[b]{2}{*}{ Factor } & \multicolumn{3}{|c|}{ Yield (kg per tree) } & \multicolumn{3}{|c|}{ Number per 100 units } \\
\hline & 2012 & 2013 & Total & $\begin{array}{l}\text { Split } \\
\text { open }\end{array}$ & $\begin{array}{l}\text { Non-split } \\
\text { open }\end{array}$ & Others $^{a}$ \\
\hline \multicolumn{7}{|l|}{ ANOVA test ${ }^{b}$} \\
\hline Treatment & NS & NS & NS & NS & NS & NS \\
\hline Rootstock & NS & $* * *$ & NS & ** & $* *$ & NS \\
\hline Treat $\times$ rootstock & NS & NS & NS & NS & NS & NS \\
\hline \multicolumn{7}{|c|}{ Tukey's multiple range test ${ }^{c}$} \\
\hline \multicolumn{7}{|l|}{ Treatment } \\
\hline T0 & 48.90 & 10.52 & 59.42 & 69.3 & 23.2 & 7.5 \\
\hline T1 & 35.79 & 12.17 & 47.73 & 70.2 & 19.0 & 10.8 \\
\hline $\mathrm{T} 2$ & 35.56 & 13.34 & 49.13 & 67.8 & 25.0 & 7.2 \\
\hline \multicolumn{7}{|l|}{ Rootstock } \\
\hline P. atlantica & 42.00 & $16.98 \mathrm{a}$ & 58.98 & $72.8 \mathrm{a}$ & $20.2 b$ & 7.0 \\
\hline P. integerrima & 40.11 & $10.23 b$ & 50.34 & $59.7 b$ & $32.0 \mathrm{a}$ & 8.3 \\
\hline P. terebinthus & 38.14 & $8.83 b$ & 46.97 & $74.8 a$ & $15.0 \mathrm{~b}$ & 10.2 \\
\hline \multicolumn{7}{|c|}{ 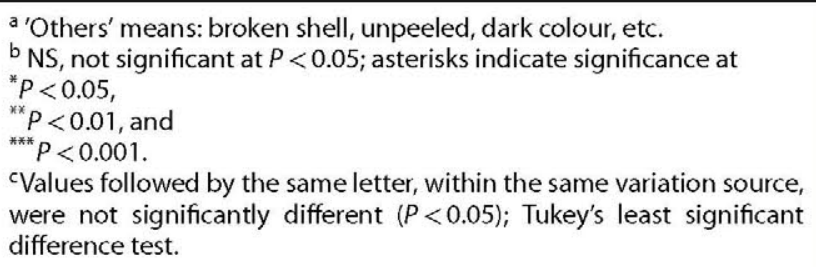 } \\
\hline
\end{tabular}

certified reference material (CRM) and one spike - were included to assess precision and accuracy for chemical analysis. The certified material selected for the current experiment was GBW07603 (bush, branches and leaves); this material was produced by the Institute of Geophysical and Geochemical Exploration of China (GBW07603) and was selected because the juices under analysis have significant amounts of solid vegetal material. Calibration curves were used for the quantification of minerals and showed good linearity $\left(R^{2} \geq 0.998\right)$. Analyses were run in triplicate.

\section{Extraction procedure of volatile aroma compounds}

Headspace solid-phase micro-extraction (HS-SPME) was the method selected to study the volatile composition of the pistachios under analysis. After several preliminary tests to optimize the extraction system, $5 \mathrm{~g}$ finely ground pistachios plus $15 \mathrm{~mL}$ ultrapure water were hermetically placed in $50 \mathrm{~mL}$ vials with polypropylene caps and PTFE/silicone septa. A magnetic stirring bar was added, together with $\mathrm{NaCl}(15 \%)$, and the vial was placed in a water bath with controlled temperature and stirring. Vials were equilibrated for $15 \mathrm{~min}$ at $40^{\circ} \mathrm{C}$ (to simulate mouth temperature during the chewing process) in the water bath and, after this equilibration time, a 50/30 $\mu \mathrm{m}$ DVB/CAR/PDMS fibre was exposed to the sample headspace for $50 \mathrm{~min}$ at $40^{\circ} \mathrm{C}$. This type of fibre was chosen for its high capacity for trapping fruit volatile compounds. ${ }^{12}$ A similar extraction procedure was previously carried out in tomatoes by Alonso et al., ${ }^{13}$ and in pomegranates by Melgarejo et al. ${ }^{14}$ and Vázquez-Araújo et al. ${ }^{15}$ After sampling, desorption of the volatile compounds from the fibre coating was carried out in the injection port of the GC-MS instrument for $3 \mathrm{~min}$. 
Table 2. Effect of deficit irrigation treatments and rootstock on physicochemical parameters of pistachio

\begin{tabular}{|c|c|c|c|c|c|c|c|c|c|c|c|c|c|}
\hline \multirow[b]{2}{*}{ Factor } & \multicolumn{3}{|c|}{ Weight $(g)^{a}$} & \multicolumn{3}{|c|}{ Size $(\mathrm{mm})^{\mathrm{a}}$} & \multicolumn{5}{|c|}{ Colour coordinates $^{\mathrm{a}}$} & \multirow{2}{*}{ Water activity ${ }^{\mathrm{a}}$} & \multirow{2}{*}{$\begin{array}{l}\text { Cutting } \\
\text { force } \mathrm{e}^{\mathrm{a}}(\mathrm{N})\end{array}$} \\
\hline & Whole & Edible nut & Shell & Length & Width & Height & $L^{*}$ & $a^{*}$ & $b^{*}$ & $C^{*}$ & Hue & & \\
\hline \multicolumn{14}{|l|}{ ANOVA test $^{\mathrm{b}}$} \\
\hline Treatment & NS & NS & NS & NS & NS & NS & NS & NS & NS & NS & NS & NS & *** \\
\hline Rootstock & $*$ & NS & ** & NS & NS & NS & NS & * & NS & NS & NS & NS & $* * *$ \\
\hline Treat $\times$ rootstock & $* * *$ & *** & $* * *$ & ** & $* *$ & $* * *$ & NS & NS & NS & NS & NS & NS & $* * *$ \\
\hline \multicolumn{14}{|c|}{ Tukey's multiple range test ${ }^{c}$} \\
\hline \multicolumn{14}{|l|}{ Treatment } \\
\hline T0 & 1.514 & 0.755 & 0.759 & 17.53 & 9.81 & 11.13 & 60.77 & -3.17 & 26.68 & 26.87 & 96.77 & 0.601 & $50.67 \mathrm{~b}$ \\
\hline $\mathrm{T} 1$ & 1.529 & 0.759 & 0.770 & 17.77 & 9.89 & 11.28 & 61.77 & -3.44 & 27.66 & 27.87 & 97.08 & 0.608 & $51.12 a b$ \\
\hline $\mathrm{T} 2$ & 1.525 & 0.759 & 0.766 & 17.74 & 9.79 & 11.31 & 61.48 & -3.28 & 27.45 & 27.66 & 96.78 & 0.607 & $53.56 a$ \\
\hline \multicolumn{14}{|l|}{ Rootstock } \\
\hline P. atlantica & $1.535 \mathrm{ab}$ & 0.755 & $0.780 \mathrm{a}$ & 17.81 & 9.77 & 11.20 & 61.25 & $-2.96 a$ & 27.11 & 27.27 & 96.22 & 0.610 & 52.44ab \\
\hline P. integerrima & $1.492 \mathrm{~b}$ & 0.751 & $0.741 \mathrm{~b}$ & 17.62 & 9.92 & 11.28 & 61.30 & $-3.67 b$ & 27.61 & 27.85 & 97.57 & 0.602 & $54.44 a$ \\
\hline P.terebinthus & $1.541 \mathrm{a}$ & 0.767 & $0.775 \mathrm{a}$ & 17.61 & 9.79 & 11.24 & 60.47 & $-3.26 a b$ & 27.08 & 27.28 & 96.84 & 0.603 & $50.72 b$ \\
\hline 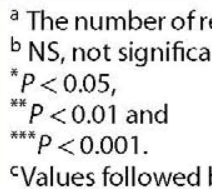 & $\begin{array}{l}\text { eplications } \\
\text { nt at } P<0 \text {. }\end{array}$ & $\begin{array}{l}\text { sfor the anal } \\
.05 ; \text { asterisk }\end{array}$ & $\begin{array}{l}\text { of we } \\
\text { icate }\end{array}$ & $\begin{array}{l}\text {, size, } \\
\text { ifican }\end{array}$ & ume & olou & & and & & & 5.2 & 20 and $20, r$ & ectively. \\
\hline
\end{tabular}

Table 3. Oil content and fatty acid composition of pistachios as affected by deficit irrigation treatments and rootstock

\begin{tabular}{|c|c|c|c|c|c|c|c|c|c|}
\hline \multirow[b]{2}{*}{ Factor } & \multirow[b]{2}{*}{ Oil content $(\%)$} & \multicolumn{8}{|c|}{ Fatty acids (\%) } \\
\hline & & $\mathrm{C} 14: 0$ & $\mathrm{C} 16: 1$ & $\mathrm{C} 16: 0$ & C18:2 & C18:1 & C18:0 & $C 20: 1$ & $\mathrm{C} 20: 0$ \\
\hline \multicolumn{10}{|l|}{ ANOVA test ${ }^{\mathrm{a}}$} \\
\hline Treatment & $* * *$ & NS & NS & NS & ${ }^{*}$ & NS & NS & NS & NS \\
\hline Rootstock & $* *$ & NS & NS & NS & * & * & * & NS & NS \\
\hline Treat $\times$ rootstock & $* *$ & NS & NS & NS & * & NS & NS & NS & NS \\
\hline \multicolumn{10}{|c|}{ Tukey's multiple range test ${ }^{b}$} \\
\hline \multicolumn{10}{|c|}{ Treatment } \\
\hline TO & $40.6 \mathrm{ab}$ & 0.11 & 1.70 & 13.58 & $31.22 \mathrm{~b}$ & 51.65 & 1.28 & 0.31 & 0.14 \\
\hline T1 & $42.1 \mathrm{a}$ & 0.11 & 1.64 & 13.40 & $33.58 \mathrm{a}$ & 49.57 & 1.24 & 0.33 & 0.13 \\
\hline $\mathrm{T} 2$ & $38.3 b$ & 0.11 & 1.68 & 13.30 & $33.30 a$ & 49.90 & 1.21 & 0.37 & 0.14 \\
\hline \multicolumn{10}{|l|}{ Rootstock } \\
\hline P. atlantica & $37.0 \mathrm{~b}$ & 0.10 & 1.71 & 13.62 & $32.13 \mathrm{ab}$ & $50.75 \mathrm{ab}$ & $1.22 \mathrm{ab}$ & 0.32 & 0.13 \\
\hline P. integerrima & $42.7 a$ & 0.12 & 1.71 & 13.30 & $34.45 a$ & $48.77 b$ & $1.17 \mathrm{~b}$ & 0.37 & 0.14 \\
\hline P. terebinthus & $41.4 \mathrm{ab}$ & 0.11 & 1.60 & 13.37 & $31.52 \mathrm{~b}$ & $51.60 \mathrm{a}$ & $1.35 \mathrm{a}$ & 0.32 & 0.14 \\
\hline $\begin{array}{l}{ }^{a} \mathrm{NS}, \text { not significa } \\
{ }^{*} P<0.05 \text {, } \\
{ }^{* *} P<0.01 \text { and } \\
{ }^{* * * *} P<0.001 \text {. } \\
{ }^{b} \text { Values followed }\end{array}$ & $<0.05$; asteris & he sam & $\begin{array}{l}\text { ce at } \\
\text {, were }\end{array}$ & ific & ent & Tuk & .0 & . & \\
\hline
\end{tabular}

\section{Chromatographic analyses}

Identification of the volatile compounds was performed on a gas chromatograph (GC-17A; Shimadzu Corp., Kyoto, Japan), coupled to a Shimadzu mass spectrometer detector (QP-5050A). The GC-MS system was equipped with a TRACSIL Meta X 5 column, $95 \%$ dimethylpolysiloxane and $5 \%$ diphenylpolysiloxane (Teknokroma S Co. Ltd, Barcelona, Spain; $30 \mathrm{~m} \times 0.25 \mathrm{~mm}$ i.d., $0.25 \mu \mathrm{m}$ film thickness). Analyses were carried out using helium as carrier gas at a flow rate of $0.6 \mathrm{~mL} \mathrm{~min}^{-1}$ in a split ratio of 1:6 and the following programme: (a) initial temperature $80^{\circ} \mathrm{C}$; (b) rate of $3.0^{\circ} \mathrm{C} \mathrm{min}^{-1}$ from 80 to $210^{\circ} \mathrm{C}$ and hold for $1 \mathrm{~min}$; (b) rate of $25^{\circ} \mathrm{C} \mathrm{min}^{-1}$ from 210 to $300^{\circ} \mathrm{C}$ and hold for $8 \mathrm{~min}$. Injector and detector temperatures were held at 230 and $300^{\circ} \mathrm{C}$, respectively. A $2 \mu \mathrm{L}$ aliquot of the extracts was always injected. ${ }^{16}$

Most of the compounds were simultaneously identified by using three different analytical methods: (i) retention indices; (ii) 
GC-MS retention times (authentic chemicals); and (iii) mass spectra (authentic chemicals and NIST05 spectral library collection ${ }^{17}$ ). Identification was considered tentative when it was based only on mass spectral data. The volatile composition analysis was run in triplicate and results were expressed as a percentage of the total area represented by each one of the volatile compounds.

\section{Sensory analyses}

Sensory evaluation with trained panel

Eight trained panellists (aged $26-60$ years; four female and four male) from the research group Food Quality and Safety (Universidad Miguel Hernández de Elche, Orihuela, Alicante, Spain) participated in this study. Each of the panellists had more than $500 \mathrm{~h}$ of testing experience with a variety of food products; the panel had a wide experience with toasted almonds and turrón (confectionery product made of toasted almonds and honey), and received further orientation on pistachio (two sessions of $1 \mathrm{~h}$ ).

Samples (pistachio nuts) were served in odour-free, disposable $90 \mathrm{~mL}$ covered plastic cups for the evaluation. A cup half filled with pistachio nuts was served to each panellist; an additional sample was available if a panellist requested it. All samples were served at room temperature and were coded using three-digit numbers. Unsalted crackers and distilled water were used to clean the palate between samples. The testing room was at $\sim 21^{\circ} \mathrm{C}$; illumination was a combination of natural and non-natural (fluorescent) light.

Three $2 \mathrm{~h}$ sessions were held for sample evaluation (the total number of samples under analysis was 9); all nine samples were evaluated in each session and thus each sample was tested in triplicate (three sessions).

The panel started to work with the lexicon developed by Vázquez-Araújo et al. ${ }^{18}$ for turrón but, after the orientation sessions the panel agreed to evaluate only the following attributes: appearance - colour and size; flavour - nutty flavour, pistachio flavour, toasted flavour, salt, sweet, and aftertaste; and texture - hardness, crunchiness, friability and adhesiveness. The panel used a numerical scale for quantifying the intensity of the pistachio attributes where 0 represents none and 10 extremely strong, with 0.5 increments. Attributes and definitions used for the present study are shown in Table 6.

\section{Sensory evaluation with consumer panel}

Consumer acceptance was studied in Spain, France, Poland and the Slovak Republic. The studies took place in April 2014. At least 60 consumers, with a ratio of men to women of $60: 40$, were recruited in each country for a central location test.

All of the participating consumers were recruited via e-mail and fliers in all participating countries. Consumers had to complete a screener stating their gender, age and diet restrictions or allergies. Consumers were asked about nut consumption frequency and willingness to taste pistachios. Consumers who stated that they were 18-67 years old, ate any kind of nut at least once per week, had no diet restrictions or allergies and were willing to taste pistachios were recruited for testing.

The ballots, screeners and demographic questionnaires were translated from Spanish to French, Polish and Slovak and then back to Spanish to confirm no major misinterpretations took place during the translation process.

Once consumers were selected, samples were served under the same preparation conditions described above in the section on sensory evaluation with trained panel.

Consumers had to complete a questionnaire about their global satisfaction degree for the samples under evaluation. Consumers
Table 4. Minerals content $\left(\mathrm{mg} \mathrm{kg}^{-1}\right)$ of pistachios as affected by deficit irrigation treatments and rootstock

\begin{tabular}{|c|c|c|c|c|c|c|c|}
\hline \multirow[b]{2}{*}{ Factor } & \multicolumn{7}{|c|}{ Minerals $\left(\mathrm{mg} \mathrm{kg}^{-1}\right)$} \\
\hline & $\mathrm{Ca}$ & $\mathrm{Mg}$ & K & $\mathrm{Fe}$ & $\mathrm{Cu}$ & $\mathrm{Mn}$ & $\mathrm{Zn}$ \\
\hline \multicolumn{8}{|l|}{ ANOVA test ${ }^{a}$} \\
\hline Treatment & NS & NS & NS & NS & * & NS & * \\
\hline Rootstock & NS & NS & NS & $* * *$ & $* * *$ & * & $* * *$ \\
\hline Treat $\times$ rootstock & NS & NS & NS & NS & NS & *** & NS \\
\hline \multicolumn{8}{|c|}{ Tukey's multiple range test ${ }^{b}$} \\
\hline \multicolumn{8}{|l|}{ Treatment } \\
\hline To & 3106 & 1113 & 10444 & 40.5 & $12.6 \mathrm{~b}$ & 2.63 & $15.5 b$ \\
\hline $\mathrm{T} 1$ & 2616 & 1128 & 10373 & 41.5 & $13.9 \mathrm{ab}$ & 2.58 & $18.1 a$ \\
\hline $\mathrm{T} 2$ & 2748 & 1172 & 10737 & 37.6 & $15.0 \mathrm{a}$ & 2.53 & $17.4 \mathrm{ab}$ \\
\hline \multicolumn{8}{|l|}{ Rootstock } \\
\hline P. atlantica & 3186 & 1149 & 10707 & $53.8 \mathrm{a}$ & $15.6 \mathrm{a}$ & $2.73 a$ & $19.0 \mathrm{a}$ \\
\hline P. integerrima & 2689 & 1141 & 10337 & $39.1 \mathrm{~b}$ & $11.6 \mathrm{~b}$ & $2.79 a$ & $14.2 b$ \\
\hline P. terebinthus & 2595 & 1123 & 10510 & $26.7 c$ & $14.3 a$ & $2.22 \mathrm{~b}$ & $17.8 \mathrm{a}$ \\
\hline \multicolumn{8}{|c|}{$\begin{array}{l}{ }^{a} N S \text {, not significant at } P<0.05 \text {; asterisks indicate significance at } \\
{ }^{*} P<0.05 \text {, } \\
{ }^{* *} P<0.01 \text { and } \\
{ }^{* * *} P<0.001 \text {. } \\
\text { b Values followed by the same letter, within the same factor, were } \\
\text { not significantly different }(P<0.05) ; \text { Tukey's least significant difference } \\
\text { test. }\end{array}$} \\
\hline
\end{tabular}

responded using a 9-point hedonic scale, where $1=$ dislike extremely and $9=$ like extremely. Consumers were then asked to indicate their order of preference for the samples, and mark the reasons why they preferred the sample from the options indicated (colour, nutty flavour, pistachio flavour, size, sweet, salt, toasted flavour, floral, woody, hardness, crunchiness and friability).

The last question in the questionnaire for each of the samples was a question of intent to purchase.

\section{Statistical analyses}

Results are provided as the mean \pm standard error. First, data were subjected to one-way analysis of variance (ANOVA) and later data were also subjected to Tukey's multiple-range test to compare the means. Differences were considered statistically significant at $P<0.05$. All statistical analyses were performed using StatGraphics Plus 5.0 software (Manugistics, Inc., Rockville, MD, USA).

\section{RESULTS AND DISCUSSION}

It is very important to mention that the RDI treatments did not significantly affect the yield and nature of pistachios in either of the two seasons under the conditions studied (Table 1). However, the rootstock significantly affected the yield per tree in the 2013 season, with $P$. atlantica $(17.0 \mathrm{~kg})$ trees having a higher yield than those of $P$. integerrima $(10.2 \mathrm{~kg})$ and $P$. terebinthus $(8.8 \mathrm{~kg})$.

The yield per tree was significantly higher in the 2012 season $(40.1 \mathrm{~kg})$ compared to that registered in the 2013 season $(12.0 \mathrm{~kg})$; this experimental finding is based on alternate bearing, a characteristic phenomenon of this type of crop.

The mean value for the split-open pistachios (commercially suitable) was 69.1\%; non-split-open pistachios (not suitable for commercialization) reached a value of $22.4 \%$, while the rest of the 
Table 5. Volatile compounds (\%) of salted and toasted pistachios as affected by deficit irrigation treatments

\begin{tabular}{|c|c|c|c|c|c|c|c|c|}
\hline \multirow[b]{2}{*}{ Compound } & \multirow[b]{2}{*}{$\begin{array}{l}\text { Retention } \\
\text { Time (min) }\end{array}$} & \multirow[b]{2}{*}{$\begin{array}{c}\text { ANOVA } \\
\text { test }^{\mathrm{a}}\end{array}$} & \multicolumn{6}{|c|}{ Content (\%) } \\
\hline & & & P. atlantica & P. integerrima & P. terebinthus & T0 & T1 & $\mathrm{T} 2$ \\
\hline Pentanal & 5.78 & NS & $4.20 a^{b}$ & $2.89 \mathrm{~b}$ & $2.92 \mathrm{~b}$ & 3.30 & 3.97 & 2.72 \\
\hline 1-Methyl-1H-pyrrole & 6.44 & * & $1.25 b$ & $1.79 a b$ & $2.82 a$ & $1.73 a b$ & $2.63 a$ & $1.24 \mathrm{~b}$ \\
\hline Hexanal & 7.13 & *** & $6.95 b$ & $8.97 a$ & $7.09 \mathrm{~b}$ & $8.17 a$ & $6.03 b$ & $9.16 a$ \\
\hline 2-Methylpyrazine & 7.78 & NS & 1.26 & 1.34 & 1.76 & 1.57 & 1.58 & 1.10 \\
\hline Furfural & 7.88 & NS & $2.51 \mathrm{~b}$ & $2.48 b$ & $3.68 a$ & 2.83 & 3.06 & 2.59 \\
\hline Heptanal & 9.23 & NS & 0.59 & 0.57 & 0.59 & 0.52 & 0.62 & 0.60 \\
\hline 2,5-Dimethylpyrazine & 9.69 & NS & 2.87 & 2.24 & 3.06 & 2.71 & 3.09 & 2.41 \\
\hline Ethylpyrazine & 9.83 & NS & 2.50 & 2.40 & 2.57 & 2.38 & 2.84 & 2.23 \\
\hline$\alpha$-Pinene & 10.33 & $\kappa * *$ & $27.98 a$ & $26.84 a$ & $20.43 b$ & $25.56 \mathrm{~b}$ & $28.65 a$ & $21.69 c$ \\
\hline 2-Heptenal & 10.86 & ** & $15.30 \mathrm{~b}$ & 16.29ab & $16.89 a$ & $16.02 b$ & $15.81 \mathrm{~b}$ & $18.31 \mathrm{a}$ \\
\hline Benzaldehyde & 11.36 & NS & 1.32 & 1.00 & 1.67 & 1.41 & 1.42 & 1.08 \\
\hline 1-Octen-3-one & 11.47 & NS & 1.16 & 1.22 & 1.46 & 1.45 & 1.22 & 1.34 \\
\hline$\beta$-Myrcene & 11.79 & * & 1.75 & 1.89 & 1.34 & $1.63 \mathrm{ab}$ & $2.00 \mathrm{a}$ & $1.39 \mathrm{~b}$ \\
\hline Octanal & 12.33 & NS & 0.86 & 1.02 & 1.02 & 0.87 & 1.04 & 1.04 \\
\hline 2-Ethyl-3-methylpyrazine & 12.47 & * & 2.99 & 2.34 & 3.09 & $2.74 a b$ & $3.11 \mathrm{a}$ & $2.66 \mathrm{~b}$ \\
\hline 1-Octen-3-ol & 12.66 & ** & $1.17 \mathrm{~b}$ & $3.97 a$ & $4.35 a$ & $2.74 b$ & $2.73 b$ & $4.44 a$ \\
\hline Limonene & 13.48 & $* *$ & $13.90 \mathrm{a}$ & $12.26 \mathrm{ab}$ & $10.97 b$ & 12.39ab & $10.75 b$ & $14.78 \mathrm{a}$ \\
\hline 2-Octenal & 14.48 & NS & 2.08 & 2.35 & 1.95 & 2.42 & 1.57 & 2.73 \\
\hline 2,6-Dimethyl-3-ethylpyrazine & 15.26 & * & 2.20 & 1.50 & 2.11 & $1.98 \mathrm{ab}$ & $2.31 \mathrm{a}$ & 1.58 \\
\hline 2,5-Diethylpyrazine & 15.68 & NS & 0.50 & 0.41 & 0.32 & 0.42 & 0.42 & 0.39 \\
\hline Nonanal & 16.28 & $* *$ & 4.74 & 4.32 & 4.31 & $5.07 a$ & $3.62 b$ & $4.58 \mathrm{ab}$ \\
\hline Dodecane & 20.42 & NS & 0.36 & 0.38 & 0.32 & 0.41 & 0.26 & 0.38 \\
\hline Decanal & 20.83 & NS & 0.77 & 0.58 & 0.53 & 0.67 & 0.58 & 0.65 \\
\hline 2-Decenal & 23.57 & NS & 0.42 & 0.49 & 0.42 & 0.54 & 0.36 & 0.48 \\
\hline Tridecane & 26.02 & NS & 0.39 & 0.50 & 0.35 & 0.50 & 0.33 & 0.43 \\
\hline
\end{tabular}

pistachios (broken shell, unpeeled, dark colour, etc.) represented $8.5 \%$.

Again the RDI treatments did not significantly affect the weights of the whole pistachio, its edible portion or their shell (Table 2). However, the rootstock significantly affected pistachio weight (whole and shell), P. atlantica and P. terebinthus taking significantly higher values than $P$. integerrima. For example, the values for the whole weight were approximately $1.54 \mathrm{~g}$ for $P$. atlantica and $P$. terebinthus and $1.50 \mathrm{~g}$ for $P$. integerrima.

On the other hand, the size (length, width and height) of pistachio nuts was affected neither by the irrigation treatment nor the rootstock (Table 2). The mean values for the three dimensions of the nut were $\sim 17.6 \mathrm{~mm}$ (length), $9.8 \mathrm{~mm}$ (width) and $11.2 \mathrm{~mm}$ (height).

The effects of both irrigation treatment and rootstock on the colour and water activity $\left(a_{w}\right)$ of roasted and salted pistachios were negligible. However, both factors significantly affected the force needed to cut the nuts (Table 2): the higher the limitation of irrigation water, the higher the cutting force, with values increasing from $50.7 \mathrm{~N}$ in the control nuts to $53.6 \mathrm{~N}$ in $\mathrm{T} 2$ nuts. Pistacia integerrima produced the hardest nuts $(54.4 \mathrm{~N})$, while the softest were those from $P$. terebinthus $(50.7 \mathrm{~N})$. No significant correlations were found among cutting force and $a_{\mathrm{w}}$ or oil content.

The content of pistachio oil was significantly affected by RDI and the type of rootstocks studied (Table 3 ). Nuts from the T1 treatment showed the highest oil content (42.1\%), followed by control (T0) and $\mathrm{T} 2$ nuts. Additionally, P. integerrima had the highest oil content $(42.7 \%)$, with P. atlantica fruits at the opposite end (37.0\%). In the case of fatty acids, the only one affected by the irrigation treatment was linoleic acid. Water stress resulted in higher contents of this fatty acid (33.4\%), compared with $31.2 \%$ determined in control nuts. This same compound was more abundant in P. integerrima and P. atlantica than in the other rootstock.

In general, the relative abundance of fatty acids observed in Spanish pistachios followed the order $\mathrm{C} 18: 1>\mathrm{C} 18: 2>\mathrm{C} 16: 0 \gg \mathrm{C} 16: 1 \approx \mathrm{C} 18: 0>\mathrm{C} 20: 1>\mathrm{C} 20: 0 \approx \mathrm{C} 14: 0$.

The mineral composition of the salted and roasted pistachios was only slightly affected by the irrigation treatment (Table 4); only $\mathrm{Cu}$ and $\mathrm{Zn}$ contents were affected, $\mathrm{T} 1$ and $\mathrm{T} 2$ pistachios presenting higher $\mathrm{Cu}$ and $\mathrm{Zn}$ contents than controls. On the other hand, $P$. atlantica nuts contained the highest amounts of $\mathrm{Fe}, \mathrm{Cu}$ and $\mathrm{Zn}$.

In general, pistachios are a good source of $\mathrm{K}\left(\sim 10.4 \mathrm{~g} \mathrm{~kg}^{-1}\right), \mathrm{Ca}$ $\left(\sim 2.8 \mathrm{~g} \mathrm{~kg}^{-1}\right)$ and $\mathrm{Fe}\left(\sim 40 \mathrm{mg} \mathrm{kg}^{-1}\right)$.

Twenty-five compounds were identified in the volatile profile of salted and toasted pistachios (Table 5). The four most abundant compounds were $\alpha$-pinene ( $25 \%)$, 2-heptenal ( $~ 16 \%)$, limonene $(\sim 12 \%)$, and hexane $(\sim 8 \%)$. T1 nuts had the highest content of pyrazines, furans + pyrroles and terpenes, while aldehydes and alcohols + ketones predominated in $\mathrm{T} 2$ fruits.

The volatile profile of $P$. terebinthus was dominated by pyrazines, furas + pyrroles, aldehydes and alcohols + ketones, whereas $P$. 
Table 6. Appearance, flavour and texture attributes and definitions used in the study

\begin{tabular}{|c|c|c|}
\hline Attribute & Definition & References and intensities \\
\hline \multicolumn{3}{|l|}{ Appearance } \\
\hline Colour & Visual evaluation of colour intensity of sample & $\begin{array}{l}\text { Pantone } 365 c=1.0 \\
\text { Pantone } 364 c=9.0\end{array}$ \\
\hline Size & Size (length) of sample & $\begin{array}{l}\text { Length } 12 \mathrm{~mm}=2.0 \\
\text { Length } 24 \mathrm{~mm}=9.0\end{array}$ \\
\hline \multicolumn{3}{|l|}{ Flavour } \\
\hline Nutty flavour & $\begin{array}{l}\text { The nut-like aromatic that is typical of several different nuts } \\
\text { such as almonds and hazelnuts }\end{array}$ & $\begin{array}{l}\text { Mix of Diamond Slivered Almonds and Diamond } \\
\text { Chopped Hazelnuts }=9.0\end{array}$ \\
\hline Pistachio flavour & Aromatics reminiscent of pistachio & Oh! Nuts roasted pistachio $=8.0$ \\
\hline Toasted flavour & $\begin{array}{l}\text { Dark-brown impression characteristic of products cooked to } \\
\text { a high temperature; does not include bitter or burnt notes }\end{array}$ & Planters dry roasted unsalted peanuts $=5.0$ \\
\hline Salt & Fundamental taste factor, of which sodium chloride is typical & $\begin{array}{l}0.20 \% \mathrm{NaCl} \text { solution }=1.5 \\
0.50 \% \mathrm{NaCl} \text { solution }=3.5\end{array}$ \\
\hline Sweet & Fundamental taste factor associated with sucrose solution & $\begin{array}{l}3.5 \% \text { sucrose solution }=2.5 \\
10 \% \text { sucrose solution }=6.5\end{array}$ \\
\hline Aftertaste & $\begin{array}{l}\text { Time the characteristic flavour of the fruit remains in the } \\
\text { mouth after swallowing the sample }\end{array}$ & $\begin{array}{l}5 s=1 \\
20 s=10\end{array}$ \\
\hline \multicolumn{3}{|l|}{ Texture } \\
\hline Hardness & $\begin{array}{l}\text { Force required to bite completely through the sample with } \\
\text { the molar teeth. Evaluate on first bite down with the molars }\end{array}$ & $\begin{array}{l}\text { Cheese American Land O'Lakes }=3.0 \\
\text { Carrots fresh }=7.5\end{array}$ \\
\hline Crunchiness & Intensity of audible noise at first chew with molars & Oat cereal Cheerios $=6.0$ \\
\hline Friability & $\begin{array}{l}\text { Number of pieces into which the sample breaks upon } \\
\text { chewing once }\end{array}$ & $\begin{array}{l}\text { Carrots fresh }=1.5 \\
\text { Soft brownie Little Debbie }=8.5\end{array}$ \\
\hline Adhesiveness & Degree to which product sticks to the surface of teeth & $\begin{array}{l}\text { Mushrooms fresh unpeeled }=2.0 \\
\text { Cheese American Land O'Lakes }=6.0\end{array}$ \\
\hline
\end{tabular}

Table 7. Descriptive (trained panel) and affective (consumer panel) data on salted and toasted pistachios as affected by deficit irrigation treatments

\begin{tabular}{|c|c|c|c|c|c|c|c|c|c|c|c|c|c|}
\hline \multirow[b]{3}{*}{ Factor } & \multicolumn{12}{|c|}{ Descriptive sensory analysis } & \multirow{3}{*}{$\begin{array}{c}\text { Affective } \\
\text { data } \\
\text { Satisfaction } \\
\text { degree }\end{array}$} \\
\hline & \multicolumn{8}{|c|}{ Appearance and flavour attributes } & \multicolumn{4}{|c|}{ Texture attributes } & \\
\hline & Colour & Size & $\begin{array}{l}\text { Nutty } \\
\text { flavour }\end{array}$ & $\begin{array}{l}\text { Pistachio } \\
\text { flavour }\end{array}$ & $\begin{array}{l}\text { Toasted } \\
\text { flavour }\end{array}$ & Salt & Sweet & Aftertaste & Hardness & Crunchiness & Friability & Adhesiveness & \\
\hline \multicolumn{14}{|l|}{ ANOVA test $^{\mathrm{a}}$} \\
\hline Treatment & $* *$ & NS & ** & $* *$ & NS & NS & NS & * & * & * & NS & NS & * \\
\hline Rootstock & $* * *$ & NS & * & $* * *$ & ** & NS & NS & * & NS & * & $*$ & $* * *$ & $* *$ \\
\hline Treat $\times$ rootstock & NS & NS & NS & NS & NS & NS & NS & NS & NS & NS & NS & NS & NS \\
\hline \multicolumn{14}{|c|}{ Tukey's multiple range test ${ }^{b}$} \\
\hline \multicolumn{14}{|c|}{ Treatment } \\
\hline T0 & $4.5 \mathrm{ab}$ & 4.5 & $5.8 \mathrm{~b}$ & $5.8 \mathrm{~b}$ & 4.9 & 2.7 & 2.5 & 4.5 & $5.5 b$ & $5.4 b$ & 5.5 & 4.0 & $7.2 \mathrm{~b}$ \\
\hline $\mathrm{T} 1$ & $5.0 \mathrm{a}$ & 4.6 & $6.6 a$ & $6.6 a$ & 5.0 & 2.5 & 2.3 & 4.9 & $6.0 \mathrm{a}$ & $6.0 \mathrm{a}$ & 6.0 & 4.0 & $7.6 a$ \\
\hline $\mathrm{T} 2$ & $4.1 \mathrm{~b}$ & 4.8 & $6.0 \mathrm{~b}$ & $6.1 \mathrm{ab}$ & 5.5 & 2.9 & 2.3 & 4.5 & $5.8 \mathrm{ab}$ & $5.6 \mathrm{ab}$ & 5.5 & 3.9 & $7.1 \mathrm{~b}$ \\
\hline \multicolumn{14}{|l|}{ Rootstock } \\
\hline P. atlantica & $5.0 \mathrm{a}$ & 4.9 & $6.3 a$ & $6.6 a$ & $5.6 a$ & 3.0 & 2.1 & $5.1 a$ & 5.6 & $5.8 a$ & $5.6 a$ & $3.4 \mathrm{~b}$ & $7.6 a$ \\
\hline P. integerrima & $4.8 \mathrm{ab}$ & 4.5 & $5.4 \mathrm{~b}$ & $6.1 \mathrm{ab}$ & $5.1 \mathrm{~b}$ & 2.5 & 2.7 & $4.4 b$ & 5.7 & $5.9 a$ & $5.2 \mathrm{ab}$ & $4.1 \mathrm{a}$ & $7.2 \mathrm{ab}$ \\
\hline P. terebinthus & $4.3 \mathrm{~b}$ & 4.5 & $5.7 a b$ & $5.6 \mathrm{~b}$ & $5.0 \mathrm{~b}$ & 2.8 & 2.3 & $4.9 a$ & 5.5 & $5.4 \mathrm{~b}$ & $5.0 \mathrm{~b}$ & $3.4 \mathrm{~b}$ & $6.9 \mathrm{~b}$ \\
\hline $\begin{array}{l}\text { a NS, not significa } \\
{ }^{*} P<0.05, \\
{ }^{*} P<0.01 \text { and } \\
{ }^{* * *} P<0.001 \text {, respe } \\
\text { bValues followed }\end{array}$ & $\begin{array}{l}\text { ant at } P< \\
\text { ectively } \\
\text { by the s }\end{array}$ & $\begin{array}{l}<0.05 ; \\
\text { same le }\end{array}$ & ; asterisk & $\begin{array}{l}\text { s indicate si } \\
\text { thin the san }\end{array}$ & me facto & & si & . & 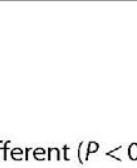 & 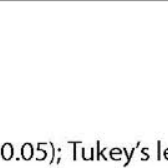 & 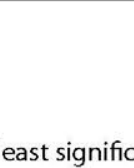 & 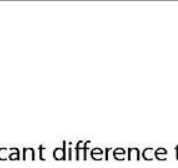 & \\
\hline
\end{tabular}

atlantica fruits were rich in terpenes. Pistacia integerrima nuts contained intermediate values of all chemical families.

The irrigation treatment significantly affected six of the main sensory attributes under analysis (all listed and described in Table 6), colour, nutty flavour, pistachio flavour, aftertaste, hardness and crunchiness (Table 7). The highest intensities of all of these six attributes were observed in $\mathrm{T} 1$ fruits, with scores of 6.6, 6.6, 6.0, 6.0, 5.0 and 4.9 for pistachio flavour, nutty flavour, hardness, crunchiness, colour and aftertaste, respectively.

Also, the preference tests showed that $56 \%, 29 \%$ and $15 \%$ of international consumers preferred samples from T1, T0 and T2, respectively. Similarly, $42 \%, 30 \%$ and $28 \%$ of international 
consumers preferred samples from P. atlantica, P. integerrima and $P$. terebinthus rootstocks, respectively.

International consumers mentioned that the main reasons for selecting the preferred sample were: pistachio flavour, $85 \%$; salty taste, $74 \%$; crunchiness, $71 \%$; and toasted flavour, $35 \%$.

A high percentage of consumers ( $85 \%$ ) were willing to buy T1 pistachios, while the percentage decreased to $56 \%$ and $53 \%$ for T0 and T2 samples, respectively. Also, consumers showed higher willingness to buy pistachios from $P$. atlantica rootstock $(71 \%)$ compared to $P$. integerrima and $P$. terebinthus (mean value of $54 \%$ ).

The experimental behaviour in which T1 (slightly stressed trees) pistachios are preferred over T0 (well-irrigated trees) and T2 (severely stressed trees) fruits, and simultaneously have higher contents of fatty acids and higher intensities of some sensory attributes, agrees quite well with the hypothesis raised by Horner. ${ }^{19}$ This author concluded that the concentration of bioactive compounds should vary nonlinearly with water deficit. In fact, the relationship between foliar tannin concentration with water status was best described by a nonlinear (quadratic) equation.

\section{CONCLUSIONS}

Based on an extensive literature search, the present work is the first study that has investigated the quality of pistachios obtained after regulated deficit irrigation, by means of physicochemical analysis and sensory analysis techniques. The results obtained in terms of the choice of rootstock revealed that $P$. atlantica has increased production yield, whole pistachio weight, mineral content, higher intensities of characteristic sensory attributes and a higher degree of consumer satisfaction than the other rootstocks studied. Moreover, the results established that the application of regulated deficit irrigation on pistachio cultivation had no significant influence on production yield, weight, size, colour, water activity and mineral composition. Furthermore, T1 treatment resulted in an overall increase in total fatty acid composition - in particular, linoleic acid - higher intensities of characteristic sensory attributes and a greater level of satisfaction among international consumers. These results confirm that the application of deficit irrigation $\mathrm{T} 1$ contributes to an increase in overall product quality and reduced water consumption during its cultivation, which carries a lower environmental and economic cost.

\section{ACKNOWLEDGEMENTS}

The authors are grateful to the projects AGL2013-45922-C2-1-R and AGL2013-45922-C2-2-R (Ministerio de Economía y Competitividad, Spain). The authors want to thank Anita Kmet'ová and Clémence Padioleau for their help in the laboratory activities.

\section{REFERENCES}

1 Kamber R, Yazar A, Önder S and Körsal H, Irrigation response in pistachio (Pistacia vera L.). Irrig Sci 14:7-14 (1993).
2 Goldhamer DA, Irrigation management, in Pistachio Production Manual, ed. by Ferguson L. Fruit and Nut Research and Information Center, University of California, Davis, CA, pp. $71-81$ (1995).

3 Gijon MD, Gimenez C, Perez-Lopez D, Guerrero J, Couceiro JF and Moriana A, Rootstock influences the response of pistachio (Pistacia vera L. Cv. Kerman) to water stress and rehydration. Sci Hortic Amst 125:666-671 (2010).

4 Fereres E, Goldhamer DA and Parsons LR, Irrigation water management of horticultural crops. Historical review compiled for the American Society of Horticultural Science's 100th Anniversary. HortScience 38:1036-1042 (2003).

5 Gijón MC, Giménez C, Pérez-López D, Guerrero J, Couceiro JF and Moriana A, Water relation of pistachio (Pistacea vera L.) as affected by phenological stage and water regimes. SciHortic Amst 128:415-422 (2011).

6 Behboudian MH and Mills TM, Deficit irrigation in deciduous orchards. Hortic Rev 21:105-131 (1997).

7 Robichaux $\mathrm{RH}$, Variation in the tissue water relations of two sympatric Hawaiian Dubautia species and their natural hybrid. Oecologia 65:75-81 (1984).

8 Ferguson L, Reyes H, Sanden B, Grattan S, Epstein L and Krueger B, Pistachio rootstocks, in Pistachio Production Manual, ed. by Ferguson L. Center for Fruit and Nut Research and Information, Davis, CA, pp. $67-73$ (2005).

9 Guerrero J, Moriana A and Couceiro JF, El Pistachero en Castilla-La Mancha, Primeros Resultados (1). Frutic Prof 173:23-38 (2003).

10 Majdi S, Barzegar M, Jabbari A and AghaAlikhani M, Supercritical fluid extraction of tobacco seed oil and its comparison with solvent extraction methods. J Agric Sci Technol 14:1043-1051 (2012).

11 Carbonell-Barrachina AA, García E, Sánchez-Soriano J, Aracil P and Burló F, Effects of raw materials, ingredients and production lines on arsenic and copper concentrations in confectionery products. $J$ Agric Food Chem 50:3738-3742 (2002).

12 Ceva-Antunes PMN, Bizzo HR, Silva AS, Carvalho CPS and Antunes OAC, Analysis of volatile composition of siriguela (Spondias purpurea L.) by solid phase microextraction (SPME). LWT - Food Sci Technol 39:436-442 (2006).

13 Alonso A, Vázquez-Araújo L, García-Martínez S, Ruiz JJ and Carbonell-Barrachina AA, Volatile compounds of traditional and virus-resistant breeding lines of Muchamiel tomatoes. Eur Food Res Technol 230:315-323 (2009).

14 Melgarejo P, Calín-Sánchez A, Vázquez-Aráujo L, Hernández F, Martínez JJ, Legua P et al., Volatile composition of pomegranates from 9 Spanish cultivars using headspace solid phase microextraction. J Food Sci 76:114-120 (2011).

15 Vázquez-Araújo L, Koppel K, Chambers E, Adhikari K and Carbonell-Barrachina AA, Instrumental and sensory aroma profile of pomegranate juices from the USA: differences between fresh and commercial juice. Flavour Frag J 26:129-138 (2011).

16 Calín-Sánchez A, Martínez JJ, Vázquez-Araújo L, Burló F, Melgarejo $\mathrm{P}$ and Carbonell-Barrachina AA, Volatile composition and sensory quality of Spanish pomegranates (Punica granatum L.). I Sci Food Agric 91:586-592 (2011).

17 NIST (National Institute of Standards and Technology). [Online]. (2011). Available: http://webbook.nist.gov/chemistry/name-ser.html [1 May 2014].

18 Vázquez-Araújo L, Chambers D and Carbonell-Barrachina AA, Development of a sensory lexicon and application by an industry trade panel for turrón, a European protected product. $\int$ Sens Stud 27:26-36 (2012).

19 Horner JD, Nonlinear effects of water deficits on foliar tannin concentration. Biochem Syst Ecol 18:211-213 (1990). 